\title{
MANAJEMEN PEMBELAJARAN AQIDAH AKHLAK BERWAWASAN MULTIKULTURAL DI MTS NEGERI 1 KEDIRI
}

\author{
Bagus Fatoni \\ Program Studi Pendidikan Agama Islam Pascasarjana IAI Tribakti Kediri \\ Moh. Turmudi \\ Institut Agama Islam Tribakti Kediri \\ moh.turmudi58@gmail.com
}

\begin{abstract}
Abstrak.
Penelitian ini bertujuan untuk mendeskripsikan (menjelaskan) manajemen pendidikan agama Islam berwawasan multikultural di MTs Negeri 1 Kediri, meliputi nilai-nilai kultural yang dikembangkan, manajemen pembelajaran pendidikan agama Islam berwawasan multikultural dalam kehidupan sehari-hari dan dampaknya terhadap minat peserta didik untuk belajar di MTs Negeri 1 Kediri. Penelitian ini menggunakan metode penelitian kualitatif. Dengan metode pengumpulan data observasi, wawancara dan dokumentasi. Teknik analisis data menggunakan model analisis interaktif yang mencakup empat komponen yaitu pengumpulan data, reduksi data, penyajian data dan penarikan kesimpulan. Pengecekan keabsahan data menggunakan empat kriteria yaitu derajat kepercayaan, keteralihan, kebergantungan dan kepastian. Hasil penelitian ini menunjukkan 1) Perencanaan pembelajaran menekankan integrasi nilai-nilai multikultural; jujur, disiplin,tanggungjawab, peduli (toleransi, gotong royong), santun, percaya diri, dalam berinteraksi secara efektif dengan lingkungan sosial termuat dalam Recana Program Pembelajaran (RPP) maupun dalam silabus; 2) pelaksanaan pembelajaran menerapkan nilai-nilai multikultural dalam perencanaan, namun yang paling menonjol adalah nilai kebersamaan dan saling menghargai tanpa mencari perbedaan; 3) Evaluasi hasil pembelajaran menggunakan model evaluasi dengan memperhatikan tiga ranah yaitu kognitif, psikomotorik dan afektif, dan yang lebih ditekankan dalam pendidikan agama Islam adalah ranah afektif.
\end{abstract}

\section{Kata Kunci : Manajemen Pembelajaran, Aqidah Akhlak, Multikultural}

\section{Pendahuluan}

Manajemen pendidikan agama Islam di setiap lembaga pendidikan perlu dikembangkan sedemikian rupa, sehingga hasil pendidikan Islam dapat benar-benar mewujudkan peserta didik menjadi kuat keimanannya dan dan ketaatannya dalam beragama, termasuk dalam pembelajaran aqidah ahlak. Sebagaimana yang terdapat di MTs Negeri 1 Kediri, pembelajaran aqidah akhlak yang berlangsung telah terlihat adanya wawasan multikultural baik dari pemahaman guru aqidah akhlak maupun dari berbagai materi yang diajarkan yang kemudian diintegrasikan dengan perilaku-perilaku multikultural. Penegasan dari kepala sekolah dan guru pendidikan agama Islam dari MTs Negeri 1
Kediri bahwa di sekolah tersebut terdapat siswa-siswi yang memiliki latar belakang sosial yang berbeda-beda, dan juga berasal dari daerah yang berbeda-beda pula di kabupaten Kediri yang dibagi menjadi 3 bagian berdasarkan kompetensi masingmasing siswa atau siswa, yaitu Akselerasi, Unggulan dan Reguler.

Keragaman ini tidak hanya berasal dari berbagai daerah atau latar belakang sosial, tetapi siswa-siswi di MTs Negeri 1 Kediri juga berbeda dalam hal mazhab yang dianut, sehingga menambah khasanah pengetahuan tentang Islam, bahwa pengetahuan Islam tidak sebatas NU ataupun Muhammaddiyah tetapi masih banyak golongan-golongan yang lain. 
Oleh karena itu, dimungkinkan bahwa pembelajaran aqidah akhlak berwawasan multikultural telah berlangsung di Madrasah tersebut karena melihat fenomena-fenomena yang telah ada. Guru aqidah akhlak memberikan pemahaman kepada para siswa yang berbeda paham (mahzab) bahwa saling menghormati satu sama lain atau toleransi dapat menjadikan suatu kerjasama yang baik antara mereka dan menghilangkan prasangka-prasangka yang salah sehingga mengikis adanya ketegangan antar siswa yang berbeda paham.

Dalam pembelajaran pendidikan multikultural di lembaga keagamaan perilaku yang dicontohkan oleh para pimpinan pendidikan memiliki nilai sangat penting untuk ditanamkan sejak dini. Sebab hal itu kumpulan nilai bermanfaat yang dapat digunakan standar pegangan hidup. Dengan demikian nilai pancasila dipahamkan pada komunitas lembaga pendidikan melalui berbagai cara. Para pemimpin sebagai sarana yang dianggap paling tepat untuk menanamkan nilai-nilai multikultural, karena didalamnya terkandung muatan nilai, moral dan norma yang diaplikasikan oleh para pemimpin dalam memerankan fungsi sosial.

Madrasah Tsanawiyah Negeri 1

Kediri merupakan madrasah yang saat ini berusaha keras meningkatkan kualitas pendidikan melalui berbagai upaya, salah satunya yaitu dengan meningkatkan pembelajaran aqidah akhlak, yang mana dirasa bahwa pembelajaran aqidah akhlak merupakan pembelajaran yang tepat untuk mencapai tujuan kurikulum 2013, yaitu "Pendidikan Karakter". Dengan pembelajaran multikultural di MTs Negeri 1 Kediri, juga diungkap bukti banyaknya minat belajar dari berbagai daerah.

Berpijak dari konteks penelitian di atas, peneliti tertarik untuk meneliti tentang Manajemen Pembelajaran Aqidah Akhlak Berwawasan Multikultural dengan mengambil lokasi penelitian di MTs Negeri 1 Kediri (MTs Negeri Pare). Sangat menarik melakukan penelitian di madrasah ini karena populasi peserta didik yang sangat banyak dan juga mempunyai latar belakang pengetahuan yang multikultural dari berbagai daerah.

Jenis penelitian ini menggunakan penelitian kualitatif. Yaitu penelitian yang berusaha menjelaskan fenomena yang terjadi. Sementara penggalian datanya menggunakan interviu, obsevasi, dan dokumnetasi. Kemudian analisis datanya menggunakan tiga tahap, yakni menguraikan data kemudian memilahmilah, dan terakhir menarik kesimpulan. Sementara tempat penelitian ini dilaksanakan di MTs Negeri 1 Kediri.

\section{Kajian Teori Tinjauan Tentang Pembelajaran Aqidah Akhlak}

Agama Islam adalah agama Allah yang disampaikan kepada Nabi Muhammad SAW, untuk diteruskan kepada seluruh umat manusia, yang mengandung ketentuan-ketentuan keimanan (aqidah) dan ketentuan-ketentuan ibadah dan muamalah (syariah), yang menentukan proses berpikir, merasa dan berbuat dan proses terbentuknya kaya hati. ${ }^{1}$

Secara umum pendidikan agama Islam merupakan mata pelajaran yang dikembangkan dari ajaran-ajaran dasar yang terdapat dalam agama Islam. Ajaranajaran tersebut terdapat dalam Al-Qur'an dan hadits serta melalui proses ijtihad para ulama' mengembangkan pendidikan agama Islam pada tingkat yang rinci. Jadi pendidikan agama Islam adalah usaha yang diarahkan kepada pembentukan kepribadian anak yang sesuai dengan ajaran agama Islam.

Pendidikan agama Islam memiliki karakteristik yang berbeda dengan mata pelajaran lainnya. Pendidikan agama Islam memiliki karakteristik sebagai berikut: (1) PAI berusaha untuk menjaga akidah peserta didik agar tetap kokoh dalam situasi dan kondisi apapun ; (2) PAI berusaha menjaga dan memelihara ajaran dan nilai-nilai yang tertuang dan terkandung dalam Al-Qur'an dan Hadits serta otentisitas keduanya sebagai sumber

1 Abu Ahmadi \& Noor Salimi, Dasar-dasar Pendidikan Agama Islam, (Jakarta: Bumi Aksara, 2004), hlm. 4 
utama ajaran Islam ; (3) PAI menonjolkan kesatuan iman, ilmu dann amal dalam kehidupan keseharian ; (4) PAI berusaha memebentuk dan mengembangkan kesalehan individu dan sekaligus kesalehan sosial ; (5) PAI menjadi landasan moral dan etika dalam pengembangan IPTEK dan budaya serta aspek-aspek kehidupan lainnya ; (6) Subsatnsi PAI mengandung entitas-entitas yang bersifat rasional dan supra rasional ; (7) PAI berusaha menggali, mengembangkan, dan mengambil ibrah dari sejarah dan kebudayaan (peradaban) Islam ; (8) dalam beberap hal PAI mengandung pemahaman dan penafsiran yang beragam, sehingga memerlukan sikap terbuka dan toleran atau semangat ukhuwah Islamiyah. ${ }^{2}$

\section{Ruang Lingkup Pembelajaran Aqidah Akhlak}

Ruang lingkup materi PAI di dalam kurikulum 1994 sebagaimana dikutip oleh Muhaimin pada dasarnya mencakup tujuh unsur pokok, yaitu: Al-Qur'an-Hadits, Keimanan, syariah, ibadah, muamalah, akhlak dan tarikh. Pada kurikulum tahun 1999 dipadatkan menjadi lima unsur pokok, yaitu: Al-Qur'an, keimanan, akhlak, fikih dan bimbingan ibadah serta tarikh yang lebih menekankan pada perkembangan ajaran agama, ilmu pengetahuan dan kebudayaan.

Dilihat secara kuantitatif, posisi pendidikan agama Islam di sekolah memang hanya tiga jam pelajaran untuk SD, dan dua jam pelajaran untuk SMP atau SMA/SMK. Mata pelajaran pendidikan agama Islam itu secara keseluruhannya dalam lingkup: Al-Qur'an dan hadits, keimanan, akhlak, fiqih atau ibadah, dan sejarah, sekaligus menggambarkan bahwa ruang lingkup pendidikan agama Islam mencakup keserasian, keselarasan, dan keseimbangan hubungan manusia dengan Allah SWT, diri sendiri, sesama manusia, makhluk lainnya maupun lingkungannya. ${ }^{3}$

2 Muhaimin, Nuansa Baru Pendidikan Islam: Mengurai Benang Kusut Dunia Pendidikan, (Jakarta: PT. Raja Grafindo Persada, 2006), hlm. 102

3 Muhaimin, hlm. 126
Aspek Al-Qur'an/Hadits menekankan pada pengembangan kemampuan mereka membaca teks, memahami arti dan menggali maknanya secara tekstual dan kontekstual untuk diamalkan dalam kehidupan sehari-hari. Aspek keimanan atau akidah menekankan pada pembinaan keyakinan bahwa Tuhan adalah asal-usul dan tujuan hidup manusia, termasuk peradaban dan ilmu pengetahuannya untuk diterapkan dalam kehidupan seharihari. Aspek ibadah menekankan pada pemahaman dan pengamalan ajaran ritual dalm Islam. Aspek syariah (fiqih) menekankan pada pengembangan tata aturan dan hukum dalam Islam yang bersifat dinamis dan untuk diamalkan dalam kehidupan sehari-hari. Aspek akhlak menekankan pada pembinaan moral dan etika Islam sebagai keseluruhan pribadi Muslim untuk diamalkan dalam kehidupan sehari-hari. Sedangkan aspek tarikh menekankan pada pemahaman terhadap apa yang diperbuat oleh Islam dan kaum Muslim sebagai katalisator proses perubahan dan perkembangan budaya umat, serta pengambilan ibrah terhadap sejarah (kebudayaan/peradaban) umat Islam. ${ }^{4}$

\section{Pendidikan Multikultural}

Dalam pengertian sederhana, pendidikan bermakna sebagai usaha untuk menumbuhkan dan mengembangkan potensi-potensi bawaan, baik jasmani maupun rohani, sesuai dengan nilai-nilai yang ada dalam masyarakat.

Multikultural merupakan suatu tuntutan pedagogis (pendidikan) dalam rangka studi kultural yang melihat proses pendidikan sebagai proses pembudayaan. Upaya kita untuk membangun masyarakat Indonesia baru yang mmulti kultural dapat dilakukan melalui proses pendidikan. Proses pendidikan merupakan proses pemberdayaan manusia Indonesia yang bebas, tetapi juga sekaligus terikat kepada suatu kesepakatan bersama untuk membangun masyarakat Indonesia bersatu

\footnotetext{
4 Muhaimin, hlm.170
} 
dalam wacana kebudayaan indonesia yeng terus menerus berkembang. ${ }^{5}$

Pendidikan Multikultural dalam Islam menemukan pijakannya dalam piagam madinah. Piagam ini menjadi rujukan suku dan agama pada waktu itu dalam menjalankan kehidupan bermasyarakat. Piagam ini juga menjadi rujukan orang-orang yang ingin menjelaskan sistem pemerintahan dan ketatanegaraan Islam. Pijakan multikultural juga bisa dilacak pada akhlak dan kepribadian Rasulullah SAW. Ia seorang manusia multikultural. Ia sangat menghormati hak asasi manusia dan menjunjung tinggi perbedaan, seperti diakui beberapa Rohaniawan non muslim, seperti Uskup Sidon Paul of Antioch, Theodore Abu Qurrah, Kenneth Cragg, dan beberapa sarjana barat, seperti William Muir, Montgomery Watt.

Kenyataan bahwa piagam Madinah dan pribadi Rasulullah menjadi pijakan multikultural, secara tidak langsung menjelaskan al-Qur'an sebagai muara pijakan tersebut. Hal ini dikarenakan dua alasan. Pertama, piagam Madinah diajukan oleh Rasulullah sebagai acuan hidup bermasyarakat karena dukungan ayat-ayat Madaniyah. Kedua, ada keterangan yang menyatakan bahwa akhlak Rasulullah adalah al-Qur'an. Artinya kedua alasan ini menegaskan bahwa pijakan pendidikan multikultural dalam Islam adalah alQur'an.6

Inovasi dan reformasi pendidikan agama Islam dalam pendidikan multikultural tidak semata menyentuh proses pemindahan pengetahuan (transfer of knowledge), namun juga membagi pengalaman dan keterampilan (sharing experience and skill). Dalam kerangka ini pendidikan agama Islam berwawasan multikultural perlu mempertimbangkan

5 Imam Machali Mustofa, Pendidikan Islam dan Tantangan Globalisasi; Buah Pikiran Seputar Filsafat, Politik, Ekonomi, Sosial dan Budaya, (Yogyakarta: Ar Ruz Media, 2004) Cet. Ke- 1, hlm. 265

6 Sunarto (Dosen PAI Fakultas Tarbiyah dan Keguruan IAIN Raden Intan Lampung), Sistem Pembelajaran PAI Berwawasan Multikultural (.pdf), hlm. 218 berbagai hal yang relefan dengan keragaman kultural masyarakat dan siswa khususnya keragaman kultur dan keagamaan. Para guru harus merefleksikan dan menghubungkan dengan pengalaman dan perspektif keagamaan siswa yang partikular dan beragam. Kebutuhan ini mencerminkan fakta bahwa proses pembelajaran dalam pendidikan agama Islam akan lebih efektif.7

Pentingnya pendidikan multikultural diberikan kepada anak sejak dini dengan harapan agar anak mampu memahami bahwa di dalam lingkungan mereka dan juga di lingkungan lain terdapat keragaman budaya. Keragaman budaya tersebut berpengaruh terhadap tingkah laku, sikap, pola pikir manusia sehingga manusia tersebut memiliki caracara (usage), kebiasaan (folk ways), aturanaturan (mores) bahkan adat istiadat (customs) yang berbeda satu sama lain. Bila perbedaan tersebut tidak dapat dipahami dengan baik dan diterima dengan bijaksana, maka konflik akan mudah terjadi di masyarakat. Hal ini telah banyak terlihat dalam kehidupan di tanah air belakangan ini. $^{8}$

Pendidikan multikultural merupakan upaya kolektif suatu masyarakat majemuk untuk mengelola berbagai prasangka sosial dengan cara-cara yang baik. Tujuannya, menciptakan hubungan lebih serasi dan kratif diantara berbagai golongan penduduk dalam masyarakat. Melalui pendidikan multikultural, siswa yang datang dari berbagai golongan dibimbing untuk saling mengenal cara hidup mereka, serta untuk mengakui dan menghormati bahwa tiap golongan memiliki hak untuk menyatakan diri menurut cara masing-masing. Beberapa hal yang dibidik dalam pendidikan multikultural ini adalah: pertama, pendidikan multikultural menolak pandangan yang menyamakan pendidikan (education) dengan persekolahan

${ }^{7}$ Sunarto, hlm. 226

8 Farida Hanum, Sisca Rahmadonna Implementasi Model Pembelajaran Multikultural di Sekolah Dasar di Propinsi Daerah Istimewa Yogyakarta, (Yogyakarta: Stranas, 2009), hlm. 2 
(schoolinng) atau pendidikan multikultural dengan program-program sekolah formal. Pandangan yang lebih luas mengenai pendidikan sebagai transmisi kebudayaan juga bermaksud membebaskan pendidik dari asumsi bahwa tanggung jawab primer dalam mengembangkan kompetensi kebudayaan semata-mata berada di tangan mereka melainkan tanggung jawab semua pihak. $^{9}$

Jadi orientasi dari pendidikan multikultural Islam ialah tertanamnya sikap simpati, apresiasi (menghargai), dan empati terhadap penganut agama dan budaya yang berbeda untuk meningkatkan kadar taqwa kita di sisi Allah. Karena Allah tidak melihat dari mana ia berasal, seberapa tampan atau cantik, seberapa kaya, seberapa tinggi pangkat/jabatan, seberapa kuat badannya, tetapi yang dilihat Allah ialah seberapa besar tingkat ketaqwaannya.

\section{Hasil Penelitian}

Manajemen pemebalajaran aqidah akhlak berwawasan multikultural merupakan suatu proses penerapan pemebelajaran PAI yang terdiri dari perencanaan, pelaksanaan dan evaluasi yang didalamnya mengandung nilai-nilai multikultural sehingga peserta didik dapat menerapkannya dalam kehidupan seharihari. Pemebelajaran aqidah akhlak berwawasan multikultural identik dengan keragaman suku, agama, ras, bahasa, budaya dan lain sebagainya. Oleh karena itu perlu adanya penanaman nilai-nilai yang dapat menjadikan perbedaanperbedaan tersebut menjadi suatu hal yang mempersatukan dan mempererat perbedaan tersebut.

MTs Negeri 1 Kediri terdiri dari siswa yang memiliki perbedaan dalam hal daerah, sosial, budaya serta lingkungan kehidupan. Meskipun dalam hal agama terdapat kesamaan namun bukan berarti sama dalam keseluruhan, namun seringkali

9 Lina Setyana, Implementasi Konteks Multikultural dalam Pembelajaran Bahasa Indonesisa Melalui Hidden Kurikulum 2011, http://cintabasindo.blogspot.co.id , Diakses pada tanggal 15 Agustus 2018 timbul adanya perbedaan-perbedaan dalam hal ibadah, kehidupan, penetapan hukum dan lain sebagainya, hal ini terjadi karena latar belakang yang berbeda antar satu peserta didik dengan peserta didik lainnya. MTs Negeri 1 Kediri merupakan madrasah yang memiliki peserta didik yang berbeda-beda dalam hal Mazhab atau pemahaman, ada NU, Muhammadiyah, dan LDII. Hasil wawancara mengenai perbedaan mazhab yaitu sebagai berikut:

Sebagaimana yang ditegaskan dalam penelitian yang terjadi di MTs Negeri 1 Kediri. Data yang diperoleh dari observasi, wawancara dan dokumentasi, diidentifikasikan agar sesuai dengan tujuan yang diharapkan, dari hasil tesebut dikaitkan dengan teori yang ada dan dibahas sebagai berikut:

\section{Perencanaan Pembelajaran Aqidah Akhlak Berwawasan Multikultural Di MTs Negeri 1 Kediri}

Ahmad Farid Huda, S.Pd. M.Pd.I berpendapat bahwa sebelum seorang pendidik melakukan proses pembelajaran maka diperlukan beberapa persiapan dan langkah-langkah diantaranya sebagai berikut: membuat program semester, program tahunan, menyusun silabus, menyusun rencana pembelajaran dan penilaian pembelajaran.

Perencanaan yang dibuat oleh seorang guru yang dilakukan dalam jangka waktu tertentu disesuaikan dengan kebutuhan, materi pelajaran, bab dan sub bab lainnya. Dengan adanya perencanaan diharapkan semua yang diprogramkan bisa terlaksana dengan baik dan tujuan pendidikan dapat dicapai. Dalam perencanaan pembelajaran aqidah akhlak berada dibawah bimbingan, kontrol dan pengawasan kepala sekolah, hal ini dimaksudkan untuk memperlancar jalannya proses pembelajaran.

Temuan

perencanaan pembelajaran pendidikan agama Islam di MTs Negeri 1 Kediri tercermin dalam nilainilai karakter baik yang termuat dalam Rencana Program Pembelajaran (RPP) maupun silabus. Dalam penyusunan RPP memuat indikator-indikator nilai-nilai 
multikultural antara lain: perilaku jujur, disiplin,tanggungjawab, peduli (toleransi, gotong royong), santun, percaya diri, dalam berinteraksi secara efektif dengan lingkungan sosial dan alam dalam jangkauan pergaulan dan keberadaannya.

Tercermin nilai-nilai multikultural dalam perencanaan pembelajaran tersebut dengan tujuan untuk menciptakan pembelajaran aqidah akhlak yang berwawasan multikultural, sehingga siswa diharapkan dapat hidup bersama dengan siswa lainnya yang berbeda daerah, suku, paham (mazhab) ras dan golongan sehingga tercipta kebersamaan, saling menghargai satu sama lainnya baik dalam segi perilaku atau sikapnya bahkan dalam hal ibadah sekalipun.

Langkah-langkah yang dilakukan guru pendidikan agama Islam sebagai berikut :

Pertama, menganalisa hari efektif dengan tujuan untuk mengetahui dan mengontrol tersampaikannya yang sudah ada dalam silabus.

Kedua, membuat program baik program tahunan maupun program semester. Ini digunakan untuk menjaga kesinambungan antara materi satu dan materi lainnya, dan untuk mengetahui kemampuan serta daya serap siswa terhadap materi yang telah disampaikan.

Ketiga, menyusun silabus. Silabus merupakan penjabaran dari standar kompetensi, kompetem]nsi dasar yang ingin dicapai, dan pokok-pokok serta uraian materi yang perlu dipelajari siswa dalam rangka mencapai standar kompetensi dan kompetensi dasar. Dengan disusunnya silabus diharapkan guru bisa mengetahui baik itu standar kompetensi, kompetensi dasar, materi pokok pelajaran yang akan disampaikan.

Keempat, menyususun RPP. Dalam menyusun RPP guru mendasarkan pada silabus dan kondisi pembelajaran agar kegiatan pembelajaran dapat berlangsung sesuai harapan. Hal ini disesuaikan dengan kondisi sekolah, siswa, metode, media serta faktor lainnya yang terkait dengan pembelajaran.
Kelima, melakukan penilaian Penilaian atau evaluasi yang diterapkan dalam pembelajaran pendidikan agama Islam adalah penilaian terhadap tiga ranah (kognitif, psikomotorik dan afektif).

\section{Pelaksanaan Pembelajaran Aqidah Akhlak Berwawasan Multikultural Di MTs Negeri 1 Kediri}

Tilaar berpendapat bahwa pendidikan multikultural adalah sebuah pendekatan pada pengajaran dan pembelajaran atas dasar menilai dan kepercayaan demokratis dan melihat keragaman sosial dan interpendensi dunia sebagai bagian dari pluralitas budaya. Multikultural dan pendidikan merupakan rangkaian kata yang berisikan esensi dan konsekuensi yang tidak dapat dipisahkan. Dalam multikulturalisme terdapat materi kajian yang menjadi dasar pijakan pelaksanaan pendidikan yang keduanya sama-sama penting. Dalam pendidikan terdapat fondasi dan akar-akar kultur yang disarikan dari nilai-nillai kultur masyarakat.

Pelaksanaan pembelajaran pendidikan agama Islam di MTs Negeri 1 Kediri berjalan lancar dan terlaksana dengan baik karena lebih menekankan pada pendekatan sosiologisnya yaitu pendekatan yang lebih mengutamakan hubungan baik antar sesama manusia tanpa mebeda-bedakan status sosial, suku, paham (mazhab), ras ataupun golongan. Siswa-siswi menyadari adanya perbedaan tersebut namun mereka tidak memandang perbedaan dapat memecah belah persatuan, namun sebaliknya mereka belajar dengan adanya segala perbedaan tersebut maka mereka mencari nilai positifnya yaitu kebersamaan dan saling menghargai.

Pendidikan multikultur adalah salah satu model pembelajaran pendidikan yang didalamnya terdapat berbagai keragaman. Dalam multikultural didalamya memuat nilai-nilai kemanusiaan yang diajarkan dalam pembelajaran, nilai-nilai luhur bangsa yang dijadikan sebagai sarana untuk mempersatukan dalam kehidupan berbangsa dan bernegara, sehingga terjalin 
hubungan yang harmonis, saling toleransi, menghargai baik satu golongan maupun golongan yang lain.

MTs Negeri 1 Kediri merupakan salah satu madrasah yang menerapkan sistem pendidikan multikultural, hal ini terbukti didalamnya terdiri dari berbagai siswa dengan latar belakang suku, daerah, paham (mazhab), golongan yang berbeda satu dan yang lainnya. Hal ini membuktikan bahwa multikultur yang ada tidak hanya lintas agama saja. Dengan adanya pebedaan latar belakang yang beragam menjadikan suatu wadah tersendiri untuk memupuk rasa saling menghargai dan menghormati, toleransi, kebersamaan dan lain sebagainya.

Dalam pelaksanaan pembelajaran pendidikan agama Islam di MTs Negeri 1 Kediri terdapat beberapa poin yang di terapkan oleh seorang pendidik yaitu sebagai berikut:

a. Strategi dalam Pembelajaran Aqidah Akhlak

Strategi pembelajaran Aqidah Akhlak yang digunakan oleh guru di MTs Negeri 1 Kediri menurut M. Misbahuddin, M.Pd.I yaitu bagaimana caranya membuat siswa cinta dengan gurunya, kemudian baru siswa akan mencintai pelajaran dan juga materi yang disampaikan oleh guru

b. Metode dan Teknik dalam Pembelajaran Aqidah Akhlak

Metode yang digunakan dalam pembelajaran pendidikan agama Islam di MTs Negeri 1 Kediri yaitu dengan metode ceramah, diskusi antar teman sebangku serta mengutamakan kondisi siswa dalam keadaan senang atau sering disebut metode pembelajaran PAIKEM (Pendidikan Aktif, Inovatif, Kreatif, Efektif dan Menyenangkan).

c. Media Pembelajaran Aqidah Akhlak

Media dalam pembelajaran pendidikana agama Islam di MTs Negeri yang sering digunakan oleh guru PAI adalah Laptop dan LCD, dimana menurut M. Misbahuddin, M.Pd.I media tersebut digunakan setelah proses penyampaian materi itu selisai, sehingga membuat siswa memiliki rasa ingin tau tentang bagaimana materi tersebut disampaikan melalui media tersebut.

d. Faktor Pendukung dalam Pembelajaran Aqidah Akhlak

Faktor pendukung dalam pembelajaran pendidikan agama Islam di MTs Negeri 1 Kediri menurut $M$. Misbahuddin,M.Pd.I sangat banyak namun yang diungkapkan oleh beliau ada dua, yaitu yaang pertama dari faktor siswanya yang memiliki IQ tinggi sehingga dalam pembelajaran siswa mudah memahami apa yang disampaikan oleh seorang guru, yang kedua dari segi sarana dan prasarana di MTs Negeri 1 Kediri sangat memadahi dibanding dengan MTs lainnya di kota Pare, Kediri.

e. Faktor Penghambat dalam

Faktor penghambat dalam pembelajaran pendidikan agama Islam di MTs Negeri 1 Kediri yaitu dari segi medianya yang sering rusak karena digunakan untuk anak-anak bermain sehingga ketika ingin digunakan menjadi tidak berfungsi dan lain sebagainya.

\section{Evaluasi Pembelajaran Aqidah Akhlak Berwawasan Multikultural Di MTs Negeri 1 Kediri}

Dalam dunia pendidikan evaluasi hasil pembelajaran di madrasah biasanya melibatkan tiga ranah yaitu kognitif, psikomotorik dan juga afektif, sedangkan pendidikan agama Islam juga melibatkan afektifnya. Evaluasi hasil pembelajaran pendidikan agama Islam di MTs Negeri 1 Kediri sama halnya yang diterapkan di sekolah umum lainnya yaitu dengan melibatkan tiga ranah tersebut dan juga diharapkan dalam evaluasi dapat memenuhi visi di MTs Negeri 1 Kediri yaitu religius, unggul, berprestasi dan terdepan dalam berkarya dan juga semboyan madrasah yaitu "Madrasah yang hebat, Madrasah yang bermartabat".

Evaluasi pendidikan multikultural ditentukan pada penilaian tingkah laku peserta didik yang meliputi persepsi, apresiasi, dan tindakan terhadap budaya lainnya. Dengan kata lain yang lebih diutamakan yaitu ranah afektif, karnea 
dalam pendidikan multikultural seorang siswa dituntut untuk saling menghormati dan mengahargai dalam perbedaan, sopan santun dalam berperilaku dalam kehidupan sehari-hari baik di lingkungan sekolah maupun di lingkungan masyarakat.

Dengan adanya integrasi anatara nilai-nilai multikultural dengan hasil evaluasi tiga ranah (kognitif, psikomotorik, afektif) maka evaluasi pembelajaran pendidikan agama Islam di MTs Negeri 1 Kediri dapat berjalan dengan baik dan tidak ada kendala. Ini membuktikan bahwa manajemen pembelajaran aqidah akhlak berwawasan multikultural di MTs Negeri 1 Kediri terlaksana dengan baik.

\section{Kesimpulan}

Berdasarkan penelitian tersebut diatas maka peneliti menyimpulkan bahwa manajemen pembelajaran pendidikan agama Islam berwawasan multikultural di MTs Negeri 1 Kediri adalah sebagai berikut:

Perencanaan pembelajaran aqidah akhlak berwawasan multikultural di MTs Negeri 1 Kediri perencanaan pembelajaran menekankan integrasi nilai-nilai multikultural : jujur, disiplin, tanggungjawab, peduli (toleransi, gotong royong), santun, percaya diri, dalam berinteraksi secara efektif dengan lingkungan sosial dan alam dalam jangkauan pergaulan dan keberadaannya.

Pelaksanaan pembelajaran aqidah akhlak berwawasan multikultural di MTs Negeri 1 Kediri pembelajaran pendidikan agama Islam diberikan melalui pendekatan sosiologis yang mengandung nilai-nilai multikultural seperti jujur, disiplin, tanggungjawab, peduli (toleransi, gotong royong), santun, percaya diri, dalam berinteraksi secara efektif dengan lingkungan madrasah maupun dalam lingkungan masyarakat.

Evaluasi pembelajaran aqidah akhlak berwawasan multikultural di MTs Negeri 1 Kediri adalah dengan menerapkan model evaluasi dengan memperhatikan nilai-nilai multikultural yang terintegrasi dalam ranah kognitif, psikomotorik dan afektif.

\section{Saran}

Setelah mengamati dan menganalisa data yang berhasil diperoleh peneliti serta dari hasil kesimpulan diatas, maka penulis menyampaikan saran-saran kepada semua pihak yang berada dilingkungan MTs Negeri 1 Kediri khususnya para siswa siswi dan guru sebagai berikut:

1. Dalam pembelajaran pendidikan agama Islam berwawasan multikultural di MTs Negri 1 Kediri, sebaiknya pihak guru dan waka kurikulum lebih memberikan porsi yang lebih dalam materi pembelajaran multikulturan yang ada di mata pelajaran IPS. Hal ini dimaksudkan untuk menambah pengetahuan siswa terkait dengan keanekaragaman yang ada di sekitar mereka khususnya di lingkungan madrasah dan masyarakat, serta umumnya di Negara Kesatuan Republik Indonesia (NKRI).

2. Madrasah sebaiknya lebih mefasilitasi dan menekankan pada pembelajaran di luar lingkungan madrasah. Hal ini dimaksudkan agar siswa siswi di MTs Negeri 1 Kediri lebih memahami apa hakikat multikultural itu dan seberapa pentingnya hidup dalam toleransi itu. 


\section{Daftar Pustaka}

Abdul Rahman Shaleh, 2000, Pendidikan Agama dan Keagamaan, Visi, Misi dan Aksi, Jakarta: Gemawindu Pancaperkasa.

Abd Rachman Assegaf, 2009, "Kata Pengantar" dalam Syamsul Kurniawan, Pendidikan Dimata Soekarno; Modernisasi Pendidikan Dalam Pemikiran Soekarno, Jogyakarta: Ar-Ruzz Media Group.

Abdul Majid dan Dian Andayani, 2005, Pendidikan Agama Islam Berbasis Kompetensi; Konsep dan Implementasi Kurikulum 2004, Bandung: Remaja Rosdakarya

Abu Ahmadi \& Noor Salimi, 2004, Dasardasar Pendidikan Agama Islam, Jakarta: Bumi Aksara

Ahmadi, 2005, Ideologi Pendidikan Islam Paradigma Humanisme, Teosentris, Yoyakarta: Pustaka Pelajar

Ainul Yaqin, 2005, Pendidikan Multikultur; Cross-Kultur Understanding untuk Demokrasi dan Keadilan,Yogyakarta: Pilar Media

Andre Ata Ujan, dkk, 2009, Multikulturalisme Belajar Hidup Dalam Perbedaan, Jakarta Barat: PT. Indeks

Al-Qur'an dan Terjemahannya. 1990. Semarang: Menara Kudus

Choirul Mahfud, 2010, Pendidikan Multikultural, Yogyakarta: Pustaka Pelajar

Darwin Syah, 2007, Perencanaan Sistem Pengajaran Pendidikan Agama Islam, Jakarta: Gaung Persada

Deddy Mulyana, 2004, Metodologi Penelitian Kualitatif, Bandung: PT. Siswa Rosdakarya

Farida Hanum, Sisca Rahmadonna, 2009, Implementasi Model Pembelajaran
Multikultural di Sekolah Dasar di Propinsi Daerah Istimewa Yogyakarta, Yogyakarta: Stranas

Hartono, Bagaimana Menulis Tesis Yang Baik, Malang: UMM Press

Imam Machali Mustofa, 2004, Pendiidkan Islam dan Tantangan Globalisasi; Buah Pikiran Seputar Filsafat, Politik, Ekonomi, Sosial dan Budaya, Yogyakarta: Ar Ruz Media

Lexy J. Moeloeng, 2006, Metode Penelitian Kualitatif: Edisi Revisi, Bandung: PT. Remaja Rosdakarya

Lina Setyana, 2011, Implementasi Konteks Multikultural dalam Pembelajaran Bahasa Indonesisa Melalui Hidden Kurikulum. http://cintabasindo. blogspot.co.id

Melayu S.P Hasibuan, 2007, Manakemen Dasar, Pengertian dan Masalah, Jakarta: PT. Bumi Aksara

Muhaimin, 2006, Nuansa Baru Pendidikan Islam : Mengurai Benang Kusut Dunia Pendidikan, Jakarta : PT. Raja Grafindo Persada

Muhaimin, 2003, Arah Pengembangan Pendidikan Islam ; Pemberdayaan, Pengembangan Kurikulum, hingga Redefinisi Islamisasi Ilmu Pengetahuan, Bandung: Nuansa

Nurani Soyomukti, 2010, Teori-teori Pendidikan; Tradisional , (Neo) Liberal, Marxis-Sosialis, Postmodern. Jogyakarta: Ar-Ruzz Media Group

Sugiyono, 2006, Metode Penelitian Pendidikan Pendekataan Kuantitatif, Kualiatatif, dan $R \& D$, Bandung: Alfabeta

Suharsimi Arikunto, 1996, Prosedur Penelitian Suatu Pendekatan Praktek, Solo : Rineka Cipta

Sumadi Suryabrata, 1992, Metodologi Penelitian, Jakarta, Rajawali Press 
Jurnal Pendidikan dan Studi Keislaman

Sunarto (Dosen PAI Fakultas Tarbiyah dan Keguruan IAIN Raden Intan Lampung), Sistem Pembelajaran PAI Berwawasan Multikultural

Tilaar, 2004, Multikulturalisme, Tantangantantangan Global Masa Depan Dalam Transformasi Pemdidikan Nasional, Jakarta: Grasindo

Undang-Undang RI No. 20 Tahun 2003 Tentang Sistem Pendidikan Nasional

Winamo Surakhmad, 1990, Pengantar Penelitian Ilmiah Dasar Metode dan Teknik, Bandung: Penerbit Tarsio

Zakiah Daradjat, et.al. 1995, Metodik Khusus Pembelajaran Agama Islam, Jakarta: Bumi Aksara 